\title{
Smart cities of the future: An interdisciplinary literature review. Dimensions and proposed characteristics
}

\author{
Sergio Vázquez Rosas ${ }^{1,2}$, Diana Faviola Olea Flores ${ }^{1}$, Arely Vallejo \\ Hernández², Uriel Alejandro Hernández Sánchez²
}

\footnotetext{
${ }^{1}$ Centro Interdisciplinario de Posgrdos, Universidad Popular Autónoma del Estado de Puebla, Puebla, México. Email: Sergio.vazquez@upaep.edu.mx,dianafaviola.olea@upaep.edu.mx

${ }^{2}$ Ingeniería en Mantenimiento Industrial, Universidad Tecnológica del Centro de Veracruz, Veracruz, México Email: sergio.vazquez@utcv.edu.mx, arely.vallejo@utcv.edu.mx, alejandro.hernandez@utcv.edu.mx
}

\begin{abstract}
The purpose of this article is to classify knowledge of the state of the art about intelligent cities and their various perspectives in which it has been discussed; a qualitative methodology is employed in the review process for the analysis of terms. Several definitions, dimensions and applications of the elements that integrate an intelligent city were located, being the common one in all intelligent cities the presence of the technologies of the information and communication, although it is a not unified concept similar characteristics were detected that look for to improve the quality of life of its inhabitants and the optimization of the resources that are in the city. The results obtained from the literary review show that intelligent cities are based on a model with different dimensions according to the conditions of the same, the implementation of such models tend in the future to generate characteristics such as social openness, stable economy, low unemployment rates, promote equality among citizens. Finally a model is proposed that arises from the literary revision, this model includes aspects like; Economy, environment, intelligent government, people and mobility as dimensions that can improve the quality of life of its inhabitants.
\end{abstract}

Keywords-Applications, Information Technologies and communication, Reference models, Smart cities.

\section{INTRODUCTION}

The relationship that exists between the human aspect, government, environment and economy, which interact with each other to satisfy needs, according to Howard (1965) proposes the concept of garden city that seeks to reverse the impacts of the modern city; as numerous environmental, social and economic crises. In metropolitan areas, initiatives have been generated that serve as support to improve infrastructure, urban services, improve the environment, social and economic conditions, as well as improve the attractiveness and competitiveness of the cities where they are applied (Yigitcanlar and Bulu, 2014; Trindade, Hinnig, Da Costa, Marques, Bastos, and Yigitcanlar, 2017).

The concept of garden city has evolved according to various academic publications with different approaches and approaches, the above is done a literary review to understand the necessary elements for the development of a new term that is based on the use of information and communication technologies (ICT) for the development of intelligent cities (Albino, Berardi and Dangelico, 2015).
Intelligent cities arise as a way of addressing the needs of societies, where ICTs function as support tools to ensure social cohesion, security and sustainability, it is also necessary to mention their application in the area of health, mobility, energy use, education, knowledge transfer and human governance (Hotelescu, Lucaciu, Andone, Cismariu, Grosseck, Slavici, 2017; Alvarado, 2018).

In the 21 st century, a worldwide process of urbanization has flourished, which has brought with it that cities have to face new challenges, such as the growing concentration of the population, the increase in consumption levels, greater mobility needs or the increase in the demand for citizen safety and participation in decisions. These new challenges affect different areas of the city, so the solution must be approached with an integrated and innovative vision from all perspectives and key areas of the city (Ramirez, 2016). This document seeks to classify the knowledge of the state of the art on intelligent cities and their different perspectives in which it has been treated; in the following works published since 2007 are analyzed. 


\section{LITERATURE REVIEW}

During the literary review it was detected that there are diverse cases of investigation that approach the topic intelligent city, from the perspective of the author different definitions have been generated from the characteristics that integrate the case study, of there is no exact definition of the construct and with recurrence it tends to show itself as a starting point to be a progressive and inclusive city, besides being an indicator of development in urban areas for the European Union (Hollands, 2008).

\subsection{Smart Cities}

There are different definitions of what an intelligent city is, so variations are present when replacing the term intelligent in a similar way with digital or intelligent. This leads to an inconsistent application, so that there is no single definition or defined scheme. In the 1990s, the California Institute for Intelligent Communities began work to determine the possibility that communities could be intelligent and cities could be planned based on the application of ICTs (O'Grady and O'Hare, 2012; Albino et. al., 2015), and the concept of intelligent city emerged from previous work.

According to Toppeta (2010), an intelligent city is a geographic space that unites ICTs and the social Web or Web 2.0 where bureaucratic processes are streamlined through user interaction, which facilitates the sharing of information, encouraging collaboration and identification of solutions to make city management more efficient, in order to direct it towards sustainability and habitability. For Batty, Axhausen, Fosca, Pozdnoukhov, Bazzani, Wachowicz, Ouzounis and Portugali (2012) is a city with high and advanced technology, with the aim of linking people, data and components of the city through the application of new technologies.

On the other hand Nam and Pardo (2011) argue that intelligent cities seek to develop an environment for the exchange of information, cooperation, capacity so that its components can be compatible with others, in addition to not present restrictions with new elements in the future, therefore its inhabitants accept technological innovation as a way in which services are modernized and ICT is used as the main element to provide infrastructure, platforms and solutions.

For Sikora-Fernandez (2017) an intelligent city is where advanced technologies are applied, with the aim of offering efficient mobility and communication systems, public lighting, public safety, optimization of natural resources. People who live in an intelligent city must have creative thinking and have the ability to include in their daily activities the use of technical and technological innovations.
Smart cities are integrated by technological systems based on advanced data processing in order to offer a more efficient government, which generates happy citizens, prosperous companies and a sustainable environment (Trilles, Granell, Degbelo and Bhattacharya, 2017). The common characteristics presented by intelligent cities according to Gil-García, Pardo and Nam (2015) is an urban context linked to technology, the application of ICT in their activities, which form a network structure integrated to the physical structure. Another feature that includes is the search to improve services to the population through the combination, interconnection and integration of systems and infrastructure.

A smart city is characterized by connectivity and structures of urban systems are clear, simple and malleable, using information technologies for efficient solution and informed citizens (Mahizhnan, 1999). According to Hall (2000) City that establishes conditions in its infrastructure that allows mobility, in a way for the optimization of resources to provide better services to its inhabitants. Territory with the ability to learn and innovate, based on the creativity of the population, institutions and digital infrastructure for communication and knowledge management (Komminos,2009).

An interconnected city with the capacity to capture and integrate information in real time, by means of sensors, personal devices, meters and similar devices that store them in platforms to generate communication between the different services of the city. (Harriso, Eckma, Hamilton, Hartswick,, Kalagnanam, Paraszczak y Williams, 2010). Nam y Pardo (2011) mention that a smart city is the Application of information in the structure of the city to optimize the conditions of life, facilitates transport, care of the environment, air, water and waste, collects information for an allocation resources and share data to collaborate across entities and domains. While Caragliu, Del Bo y Nijkamp (2011) they argue they argue, it is a City where human capital integrates modern factors such as ICT in a common urban environment, to generate a better quality of life, adequate management of natural resources and economic growth through the management of participatory government.

A city that integrates ICT merged with traditional infrastructure as an effective way of coordinating urban technologies; methods for applying urban data at spatial and temporal scales through new forms of governance, to create a competitive and innovative sustainable city, better trade and better quality of life (Batty et al., 2012). According to Angelidou (2014) the concept intelligent city conglomerates themes such as intelligent urbanism, intelligent economy, sustainable environment, intelligent 
mobility, health and quality of life. While Maestre and Nieto (2016) mention the intelligent city as a territory characterized by the intensive use of technologies, mainly information and communication, to promote collaboration, innovation and efficiency in improving the quality of life and sustainability of cities through technological services to citizens.

An intelligent city is a concept closely linked to ICT for sustainable economic development, natural resource management, generating a better quality of life, for the management of future urban development (Baucells, Moreno y Arce, 2017). Vision of the future in six dimensions; competitiveness, human and social capital, participation, transport and ICT, natural resources and quality of life, developed on an intelligent combination of endowments and activities (Gascó-Hernández, 2018).

\subsection{Smart City Models}

To develop and implement intelligent cities requires experts in various fields; economics, sociology, engineering, politics and information technologies. The literary review revealed the existence of various models proposed by researchers, most of which consist of six dimensions or components: government, economy, mobility, environment and people (Gil-García et al., 2015). Gascó-Hernández (2018) highlights the importance of linking physical and digital infrastructure to create intelligent cities in which its structure in six dimensions stands out: intelligent economy, human and social capital, intelligent government, mobility, intelligent environment and quality of life. While Nam and Pardo (2011) argue the existence of three dimensions in an intelligent city; technology as the axis of transformation, people as human capital and community as support to the government.

Kumar, Graham, Hennelly and Srai (2016) propose a model in which they seek to understand how the intelligent city model can change the furuta supply chain, and propose a model in which they interact; manufacturing systems, supply chain, technology, processes, people, information flow and value structure. An intelligent city is not only technology, it must also be taken into consideration that technology is at the service of the inhabitants, so Trilles et al. (2016) mentions an intelligent city model which divides it into three areas; empowerment of people through citizen participation and citizenship literacy, a second area methods and tools of analysis in which qualitative and quantitative data are linked for the adoption of standards, and finally an area for services based on citizens such as personal services and persuasive user-centered interfaces.
According to Maestre and Bernal (2011) an intelligent city should generate investments in human capital (education), social capital, physical infrastructure and communication infrastructure are sustainable dimensions that generate economic growth to generate quality of life for its population. Komninos (2009) identifies four dimensions in an intelligent city, starting with the dimension that includes various electronic and digital components that build the digital environment, wireless with data flowing and fed the government processes; the second dimension is the application of new technologies to make a transformation of the quality of life; the third dimension detected is the integration of ICT to the physical infrastructure and finally highlights the creation of a lifestyle where one can innovate, learn and develop knowledge.

Griffinger, Fertner, Kramar, Meijers and PichlerMilanovic (2007) present a model in which they talk about dimensions in intelligent cities, which they identify as intelligent factors; Smart economy, smart environment, smart governance, smart living, smart mobility and smart people, are measured by the application of national and international indicators. According to Lim, Kim and Maglio (2018) detected 12 areas where an intelligent city can be applied; intelligent device", "intelligent environment", "intelligent home", "intelligent energy", "intelligent building", "intelligent transport", "intelligent logistics", "intelligent agriculture", "intelligent safety", "intelligent health", "intelligent hospitality" and "intelligent education". As part of the literature review, several models composed of key dimensions of an intelligent city that are supported by various authors were detected, and the proposed models are shown in TABLE 1. One of the most named dimensions in the works is the economic part applied to knowledge, which arises from the application of research and development, followed by technology transfer between academia and industry, thereby encouraging the development of innovative and high-tech enterprises (Gil-García et al., 2015). The intelligent economy then becomes a competitive advantage in the cities where it is applied; when migrating to ECommerce or electronic commerce, not only is a system or platform required, a legal system is required to track electronic intellectual property, identification of people, contracts, transactions. Therefore, manipulation-proof equipment must be available to guarantee the security of users (Mahizhnan, 1999).

Intelligent cities are developed according to the needs, characteristics, priorities, in addition to the technology available at the local level, there is currently no literature that mentions the theory of extrapolating the strategies 
applied in the intelligent city to migrate to the concept of intelligent country (Angelidou, 2014). City dwellers aspire to a wide range of services and facilities, green spaces, efficient transport, beauty and good signage, a sense of community and safe environments; they seek personal well-being. However, it has been detected that only a small part of the population is interested in aspects of environmental relations, cities also emit large amounts of emissions into the atmosphere, what an intelligent city seeks from the environmental dimension is to reduce carbon emissions into the atmosphere (Joffe and Smith, 2016).

Table 1. Dimensions in the smart cities model

\begin{tabular}{|c|c|}
\hline Key Dimensions & Source \\
\hline $\begin{array}{l}\text { Economy } \\
\text { Environment } \\
\text { Governance } \\
\text { Mobility } \\
\text { People }\end{array}$ & $\begin{array}{l}\text { Griffinger et al. } \\
(2007)\end{array}$ \\
\hline Governance & \\
\hline $\begin{array}{l}\text { Technology } \\
\text { Economy } \\
\text { Infrastructure } \\
\text { Environment } \\
\text { Politics } \\
\text { People }\end{array}$ & $\begin{array}{l}\text { Nam y Pardo } \\
\text { (2011) }\end{array}$ \\
\hline $\begin{array}{l}\text { Smart economics } \\
\text { Intelligent people } \\
\text { Intelligent governance } \\
\text { Intelligent mobility } \\
\text { Intelligent environment } \\
\text { Smart Life }\end{array}$ & Batty et al (2012) \\
\hline $\begin{array}{l}\text { Environment and energy } \\
\text { Transport and mobility } \\
\text { Buildings } \\
\text { Housing } \\
\text { Government } \\
\text { Economy } \\
\text { People }\end{array}$ & $\begin{array}{c}\text { Neirotti, De } \\
\text { Marco, Cagliano, } \\
\text { Mangano, } \\
\text { Scorrano (2014) }\end{array}$ \\
\hline Public services & \\
\hline $\begin{array}{l}\text { Administration and } \\
\text { municipal management } \\
\text { Human capital and creativity } \\
\text { Growth economy } \\
\text { Infrastructure and } \\
\text { environment } \\
\text { Big data, ICT and other } \\
\text { technologies }\end{array}$ & $\begin{array}{l}\text { Gil-García et al. } \\
\qquad(2015)\end{array}$ \\
\hline
\end{tabular}

Economy

Environment

Transport and

communications

People

Quality of life

Intelligent management

Smart economics

Intelligent environment

Intelligent governance

Intelligent Life

Intelligent mobility

Intelligent people

Source: Own preparation

\subsection{Smart City applications}

Smart cities provide services to their inhabitants through their own resources or subcontracted according to needs. Although this has always been done, it is now done through digital assets which can be used by their inhabitants; a set of data and digital resources, which allows complementary services to be offered with greater access and lower cost from the existence of more technology (Abella, Ortiz de la Urbina and De Pablos, 2015).

Intelligent cities have a difference compared to the rest of the cities, that difference is to have a virtuality to contribute in a more agile and efficient way, to a larger number of the population, which produces an increase in the economic and social progress of the physical city. The services available in intelligent cities according to Vivas, Britos, García-Martínez and Cambarieri (2013) are classified into three groups; citizen services where the dimensions of environment, education, intelligent government, health, work are applied, they can also count on e-commerce services offering E-Learning, GeoMarketing, Digital Contents, B2B and B2C ecommerce, and finally free access services such as education, religion, addiction prevention and senior citizens.

According to Benítez and Ortega (2015), 70\% of Europe's energy capacity is consumed in the four large cities where $68 \%$ of the continent's population is concentrated; Paris, Madrid, London and Berlin. One of the main challenges presented by these cities is to reduce the impact on the environment, maintain economic development and improve the quality of life of their inhabitants with the support of intelligent electricity grids for energy management through; measurement from sensors and monitoring, demand management, energy efficiency 
programs, integrating alternative energy sources and distributed storage.

In order to make mobility more efficient and less polluting, cities have opted to offer inhabitants a non-motorized transport system, while also seeking to reduce the number of automobiles in the city. In intelligent cities, the use of bicycles as a non-motorized means is promoted, as well as the use of dissuasive parking, calm traffic of $30 \mathrm{Km} / \mathrm{h}$, vehicle sharing, improvement of public transport, with the aim of improving mobility in large cities (Segui, Mateu, Ruiz and Martínez, 2016).

In order to have an efficient mobility system, it is necessary to apply ICTs to manage demand and provide services through traffic analysis systems, route mapping, demand analysis and payment management. This brings benefits for administrators and users, where strategies can be established to reduce traffic congestion, city planning, new transport systems from applications, forms of electronic payment or prepaid cards (Tablecloth, 2015).

Another application of smart cities is the health sector, which seeks to improve the quality of life of citizens and for this can be used data analysis and decision making in health services by applying data mining, analysis of neural networks and decision trees, descriptive analysis and the use of specific software. In order to provide a better service and quality of life to users, the support of the system can be reinforced through big data databases (Oviedo, Oviedo and Vélez, 2015).

\section{METHODOLOGY}

The present research was developed by choosing the type of qualitative approach with an exploratory scope because it examines the existing information on intelligent cities in a period from 2013 to 2018 . The term or definition of Intelligent Cities in the last decade has been approached by several authors and has had to be analysed from different perspectives and relevant changes according to its application. For the development of the present work, the methodology used consisted of 4 stages: Obtaining the information, Selecting the information, identifying and synthesizing the information.

For the development of this work, publications (journal articles, conferences and books) were searched in the database Scopus and emerald, with the following search criteria: keywords, smart cities in the fields of titles, abstract and key words, then the publication period 20132018. On the basis of these search criteria according to TABLE 2, a total of 108 papers were identified, of which a content discrimination was initiated.
Table 2. Database consulted

\begin{tabular}{cc}
\hline Database & Paper \\
\hline Scopus & 78 \\
Emerald & 30 \\
Total & 108 \\
\hline
\end{tabular}

Source: Own preparation

From the previous search, the works began to be discriminated according to the contributions on the subject, considering those works that deal with subjects such as: mobility, intelligent environment, intelligent economy, governance, use of information technologies, people and quality of life. Once the previous points were concluded, the articles were read, identifying the areas of application, the contributions and definitions of the exposed authors.

\section{CONCLUSION}

The literary review shows that the common in all intelligent cities is the presence of information and communication technologies, although it is with nonunified concept were detected similar characteristics such as seeking to improve the quality of life of its inhabitants and optimization of resources found in the city. The cities where the concept of intelligent city is applied have determined characteristics such as: social openness, stable economy, low unemployment rates, promote equality among citizens.

An intelligent city is sustained in a model that is supported in diverse dimensions according to the author and to the characteristics of the city, a total of 10 models proposed by diverse authors were analyzed in where it is possible to be observed that the common dimension between them is that it must have a mobility, economic and environment. Mobility is required for its inhabitants by reducing travel times, offering less polluting transport, must be highly competitive cities that promote commerce and ecommerce, and finally must seek to be sustainable cities.

In order to determine the degree of implementation of the concept of intelligent city in Poland, the actions carried out by the government are identified and evaluated by making a relation with the intelligence of the activities of management, exchange of information between inhabitants. Roman's study (2018) detected that the lack of coordination between the development and manufacturing activities of the systems used generates an inefficient use of resources in the urban structure, as a consequence it has a negative impact on the complexity of the city.

According to the revised literature is proposed a model with the dimensions and characteristics, agree with the revision should contain an intelligent city according to TABLE 3, within a city there should be a solid economy where it promotes the development of innovative 
enterprises and high technology and has a large presence of transactions through electronic commerce. The means should be sought to have a sustainable city where there are green spaces for various activities, have gardens in houses, vertical gardens, program for reducing emissions into the atmosphere, with the aim of offering quality of life to its inhabitants.

Table 3. Dimensions and proposed characteristics

\begin{tabular}{|c|c|c|c|}
\hline \multirow{3}{*}{$\begin{array}{c}\begin{array}{c}\text { Dimensio } \\
\mathbf{n}\end{array} \\
\text { Economy }\end{array}$} & \multicolumn{3}{|c|}{ Characteristics } \\
\hline & E-Comerce & Innovation & $\begin{array}{l}\text { Entreprene } \\
\text { urship }\end{array}$ \\
\hline & $\begin{array}{l}\text { Productivit } \\
\mathrm{y}\end{array}$ & $\begin{array}{l}\text { International } \\
\text { integration }\end{array}$ & $\begin{array}{l}\text { Economy } \\
\text { and brands }\end{array}$ \\
\hline $\begin{array}{l}\text { Environ } \\
\text { ment }\end{array}$ & $\begin{array}{l}\text { Environme } \\
\text { nt } \\
\text { protection }\end{array}$ & $\begin{array}{l}\text { Sustaninable } \\
\text { management }\end{array}$ & $\begin{array}{l}\text { Use of } \\
\text { resources }\end{array}$ \\
\hline $\begin{array}{l}\text { Smart } \\
\text { governm } \\
\text { ent }\end{array}$ & $\begin{array}{l}\text { Participator } \\
\text { y decision } \\
\text { making }\end{array}$ & $\begin{array}{l}\text { Transparenc } \\
\text { y }\end{array}$ & $\begin{array}{l}\text { Public and } \\
\text { social } \\
\text { service }\end{array}$ \\
\hline People & $\begin{array}{l}\text { Lifelong } \\
\text { learning }\end{array}$ & $\begin{array}{l}\text { Social } \\
\text { plurality }\end{array}$ & Creativity \\
\hline & $\begin{array}{l}\text { Social } \\
\text { participatio } \\
n\end{array}$ & $\begin{array}{l}\text { Highly } \\
\text { qualified }\end{array}$ & \\
\hline Mobility & $\begin{array}{l}\text { Easy access } \\
\text { Safe } \\
\text { transport }\end{array}$ & $\begin{array}{l}\text { Sustainable } \\
\text { transport }\end{array}$ & $\begin{array}{l}\text { Availability } \\
\text { of access } \\
\text { TIC's }\end{array}$ \\
\hline
\end{tabular}

Fuente: elaboración propia

According to the characteristics of each intelligent city you can count on an intelligent government that relies on the information it generates and is stored in databases in order to offer more agile processes and avoid bureaucratic procedures, thus increasing people's satisfaction. People within a smart city can usually come up with constant ideas for innovation and entrepreneurship that support the community. They can also count on an effective transportation system that reduces distances and transportation times, there must be programs that encourage the use of non-motorized means such as bicycles and the construction of special lanes for this type of transportation, the capacity of public transportation must meet the demand of the population.

\section{ACKNOWLEDGEMENTS}

An acknowledgement section may be presented after the conclusion, if desired.

\section{REFERENCES}

[1] Albino, V., Berardi, U., \& Dangelico, R. (2015). Smart Cities: Definitions, Dimensions, Performance, and Initiatives. Journal of Urban Technology, 22(1), 3-21.

[2] Alvarado López, R. A. (2018). Ciudad inteligente y sostenible: hacia un modelo de innovación inclusiva. Paakat: Revista de Tecnología y Sociedad, 7(13).

[3] Angelidou, M. (2014). Smart city policies: A spatial approach. Cities, 41, S3-S11.

[4] Batty, M., Axhausen, K., Fosca, G., Pozdnoukhov, A., Bazzani, A., Wachowicz, M., y otros. (2012). Smart cities of the future. The European Physical Journal Special Topics, 214(1), 481-518.

[5] Baucells Aletà , N., Moreno Alonso, C., \& Arce Ruiz, R. M. (2017). Smart Mobility and Smart Environment in the Spanish cities. Transportation Research Procedia, 24, 163170.

[6] Benítez, L., \& Ortega, M. (2015). Las TIC y la gestión de los desafíos de sostenibilidad energética de las ciudades inteligentes. Economía industrial, 395, 87-94.

[7] Caragliu, A., Del Bo, C., \& Nijkamp, P. (2011). Smart cities in Europe. Journal of Urban Technology, 18(2), 65-82.

[8] Gascó-Hernandez, M. (2008). Building a Smart City: Lessons from Barcelona. Communications of the ACM, 61(4), 50-57.

[9] Gil-Garcia, J. R., Pardo, T. A., \& Taewoo, N. (2015). What makes a city smart? Identifying core components and proposing an integrative and comprehensive conceptualization. Information Polity, 20(1), 61-87.

[10] Giffinger, R., Fertner, C., Kramar, H., Kalasek, R., \& Pichler-Milanović, N. (s.f.). Smart cities Ranking of European medium-sized cities.

[11] Giffinger, R., Fertner, C., Kramar, H., Kalasek, R., \& Pichler-Milanović, N. (s.f.). Smart cities Ranking of European medium-sized cities.

[12] Hall, P. (200). Creative Cities and Economic Development. Urban Studies, 37(4), 639-649.

[13] Harrison, C., Eckman, B., Hamilton, R., Hartswick, P., Kalagnanam, J., Paraszczak, J., y otros. (2010). Foundations for Smarter Cities. IBM Journal of Research and Development, 54(4), 1-16.

[14] Hollands, R. G. (2008). Will the real smart city please stand up? City, 12(3), 303-320.

[15] Holotescu, C., Lucaciu Goţiu, L. O., Andone, D., Cismariu, L., Grosseck, G., \& Slavici, T. (2017). Entrepreneurship Learning Ecosystem for Smart Cities through MOOCs. BRAIN: Broad Research in Artificial Intelligence and Neuroscience, 8(2), 33-42.

[16] Joffe, H., \& Smith, N. (2016). City dweller aspirations for cities of the future: How do environmental and personal wellbeing feature? Cities , 59, 102-112. 
[17] Komninos, N. (2009). Intelligent cities: towards interactive and global innovation environments. International Journal of Innovation and Regional Development, 1(4), 2009.

[18] Kumar, M., Graham, G., Hennelly, P., \& Srai, J. (2016). How will smart city production systems transform supply chain design: a product-level investigation. International Journal of Production Research, 54(23), 7181-7192.

[19] Lim, C., Kim, K.-J., \& Maglio, P. P. (2018). Smart cities with big data: Reference models, challenges, and considerations. Cities.

[20] Luis Vivas, H., Britos, P., García-Martinez, N., \& Cambarieri, M. (2013). Investigación en Progreso: Estudio y Evaluación de Tecnologías de la Información y la Comunicación para el Desarrollo de Ciudades Inteligentes. Revista Latinoamericana de Ingeniería de Software, 1(4), 147-151.

[21] Maestre Góngora, G. P., \& Nieto Bernal, W. (2015). Factores Clave en la Gestión de Tecnología de Información para Sistemas de Gobierno Inteligente. Journal of Technology Management \& Innovation, 10(4), 109-117.

[22] Mahizhnan , A. (1999). Smart cities: The Singapore case. Cities, 16(1), 13-18.

[23] Mantelero, A. (2015). Smart cities, movilidad inteligente y protección de los datos personales. Revista D'Internet, Dret I Política, 21(12), 37-40.

[24] Nam, T., \& Pardo, T. (2011). Conceptualizing Smart City with Dimensions of Technology, People, and Institutions . The Proceedings of the 12th Annual International Conference on Digital Government Research(págs. 282291). ACM.

[25] O'Grady, M., \& O'Hare, G. M. (2012). How Smart Is Your City? Science, 335(6076), 1581-1582.

[26] Oviedo Carrasca, E. A., Oviedo Carrasca, A. I., \& Vélez Saldarriaga, G. L. (2015). Míneria de datos: Aportes y tendencias en el servicio de salud de ciudades inteligentes. Revista Politécnica2015, 11(20), 111-120.

[27] Ramírez Autrán, R. (2016). Smart Cities: alegoría del progreso en el nuevo siglo. Idioma: Spanish. Revista Cartográfica(93), 119-123.

[28] Roman, K. (2018). Analysis and Evaluation of the Implementation Level of the Smart City Concept in Selected Polish Cities. BRAIN: Board Research in Artificial Intelligence and Neurosciencie, 9(1), 138-145.

[29] Sikora-Fernandez, D. (2017). Factores de desarrollo de las ciudades inteligentes. Revista Universitaria de Geografia, 26(1), 135-152.

[30] Sikora-Fernandez, D., \& Stawasz, D. (2016). The concept of smart city in the theory and practice of urban development management. Romanian Journal of Regional Science , $10(1)$.

[31] Toppeta, D. (2010). The Smart City vision: How Innovation and ICT can build smart, "liveable", sustainable cities. The Innovation Knowledge Foundation .

[32] Trilles, S., Granell, C., Degbelo, A., \& Bhattacharya, D. (2017). Open City Toolkit: el rol de las ciencias geoespaciales para la realización de ciudades abiertas y participativas. Mapping, 26(181), 42-50.

[33] Trindade, E. P., Farias Hinning, M. P., Moreira da Costa, E., Sabatini Marques, J., Cid Bastos, R., \& Yigitcanlar, T. (2017). Sustainable development of smart cities: a systematic review of the literature. (S. Singapore, Ed.) Journal of Open Innovation: Technology, Market, and Complexity, 3(11)

[34] Yigitcanlar, T., \& Bulu, M. (2016). Urban Knowledge and Innovation Spaces. Journal of Urban Technology, 23(9), 19. 